\title{
THE IMPACT OF FOCUSING STUDENTS' ATTENTION ON THEMSELVES AS FUTURE PROFESSIONALS ON THEIR PROFESSIONAL CALLING
}

\author{
Regina Saveljeva \\ Liudmila Rupšienè \\ Klaipėda University, Lithuania
}

\begin{abstract}
Researchers express ideas about the relationship between focusing students' attention on themselves as future professionals during their studies and students' professional calling. However, empirical evidence on this relationship is still lacking. The research aimed to answer the question: „What is the impact of focusing students' attention on themselves as future professionals on their professional calling?" In order to answer this question the quasiexperiment with the non-equivalent comparison group without the pre-test design has been carried out. The quasi-experimental programme was implemented in the experimental group of 31 student of the social pedagogy study programme of Klaipeda University in 2009-2014. The control group consisted of 79 students from three other Lithuanian universities. The final measurement was carried out in the control and experimental groups on May-June, 2014. The results argue that focusing students' attention on themselves as future professionals during their studies has an impact on their professional calling.
\end{abstract}

Keywords: professional calling, professional self-awareness, focusing attention, higher education.

\section{Introduction}

Practical relevance of the research on the development of professional calling. Although today there is no common agreement on the united concept of calling (Duffy et al., 2012) and there are no comprehensive interpretations of origins and development of calling (Praskova et al., 2014; Duffy et al., 2012; Wrzesniewski, 2012), it is usually interpreted as a relationship between individual and his professional occupation, which is expressed through inner human experiences, attitudes, abilities, and motives (Dobrow \& Tosti-Kharas, 2011; Steger et al., 2010).

Recently, the importance of professional calling has become especially emphasized (Praskova et al., 2014; Danilevičius, 2013; Hagmaier \& Abele, 2012; Hirschi, 2012), since it is stated that those employed people who have a calling 
perform their duties more diligently, see the meaning in their work, feel the inner satisfaction with their work, defend the prestige of their profession, and seek to improve their professional skills. Moreover, it is asserted that such people have a greater desire to use their professional activities to contribute to the welfare of other people and the whole community (Steger et al., 2010). More importantly, to work as a pedagogue without a calling is considered to be unethical in respect of yourself and others (Jovaiša, 1994: p. 47).

Calling is an evolving construct, it is not suddenly and fully disclosed (Wrzesniewski, 2012; Hunter et al., 2010), and, therefore, it is not by accident indicated in the scientific literature that it is important to develop professional calling of people, especially - of the young ones (Hagmaier \& Abele, 2012; Hirschi, 2012; Dobrow \& Tosti-Kharas, 2011; Duffy et al., 2011; Danilevičius, 2013). The role of a higher school in the development of students' professional calling is also highlighted (Praskova et al., 2014; Danilevičius, 2013).

Studies suggest that students' professional calling is related to satisfaction with one's life and psychological adaptation (Steger et al., 2010); it is related to satisfaction with academic and chosen career (Duffy et al., 2011; Saveljeva et al., 2011; Duffy \& Sedlacek, 2007); it is related to professional self-clarity (Duffy \& Sedlacek, 2007), clearer career vision (Dobrow \& Tosti-Kharas, 2011; Duffy \& Sedlacek, 2007) and more positive attitudes towards career (Steger et al., 2010). Meanwhile, studies on professional calling of higher school students reveal that only about half or less students have a calling for their chosen profession and it depends on the country and on the study programme (Danilevičius, 2013; Saveljeva et al., 2011; Duffy \& Sedlacek, 2010).

The provided arguments motivate the practical significance of the research on the development of students' professional calling.

The extent of the research on professional calling. Researchers who are concerned with the concept of the development of professional calling have already revealed a number of regularities, tendencies and aspects of the development of students' professional calling. It has been identified that during the development of professional calling it is appropriate to acquaint students with the concept of calling and factors that influence it (Praskova et al., 2015; Hirschi \& Herman, 2013; Duffy \& Sedlacek, 2010; Kavaliauskienè, 2001). In addition, it is stated that it is important to provide students with opportunities to assess their own calling for the chosen profession (Dik et al., 2009), to assist them in clarifying and improving their professional interests, values, and abilities (Hirschi \& Herrmann, 2012; Duffy \& Sedlacek, 2010), and to help them in identifying their career goals as well as in achieving them (Praskova et al., 2014; Duffy \& Dik, 2013). It is noted that in the course of the development of professional calling those activities are important during which a person can focus his attention to himself, such as: introspection, self-reflection, self-analysis (Wrzesniewski, 
2012), as well as social support from parents, career counsellors, pedagogues or friends (French \& Domene, 2010). Roberts and Creary (2012) point out that on the basis of social learning theory (Bandura, 1977) it can be assumed that calling can be developed by observing and imitating parents' or other persons' behaviour, by motivating to acquire and develop positive identities. Saveljeva, Rupšienè (2016), referring to the results of the quasi-experimental research and their analysis, state that providing feedback to students as future professionals during their studies play an important role in developing students' professional calling.

The research problem. As it was already mentioned, within the concept of the development of professional calling there are ideas about the impact of focusing students' attention on themselves as future professionals on their professional calling (Hirschi \& Herrmann, 2012; Wrzesniewski, 2012; Elangovan et al., 2010; Duffy \& Sedlacek, 2010; Dik et al., 2009; Dik \& Steger, 2008; Hall \& Chandler, 2005).

On the other hand, within the framework of the concept of studying at a higher education institution much attention is paid to focusing students' attention on themselves as future professionals during their studies, especially highlighting the importance of focusing students' attention on themselves on different aspects of students' personality development, self-awareness, students' professional behaviour, personal and professional development (Chang-Kredl \& Kingsley, 2014; Furlong, 2013; Haggarty \& Postlethwaite, 2012; Altinay \& Altinay, 2012; Bubnys, 2012; Rusche \& Jason, 2011; Wong-Wylie, 2010; Ivanauskienė \& Liobikienè, 2005). With reference to these facts, it is likely that there is a relation between focusing students' attention on themselves as future professionals and students' professional calling.

However, there is a lack of empirical evidence that would determine the impact of focusing students' attention on themselves as future professionals on their professional calling. It is purposeful to accomplish empirical research in order to answer the question: „What is the impact of focusing students' attention on themselves as future professionals on their professional calling?". Therefore the research aims to answer this question.

\section{Methodology}

In order to achieve the purpose of the research, the quasi-experiment with the non-equivalent comparison group design with no pre-test has been carried out (Green, Camilli, \& Elmore, 2006; Wiersma \& Jurs, 2009). Since the assignment to a control group was not random during this quasi-experiment, this group is considered to be inequivalent.

The quasi-experimental programme was implemented in the experimental group of one Lithuanian University students in 2009-2014. The control group 
consisted of students from three Lithuanian universities. The final measurement was carried out in the control and experimental groups on May-June, 2014.

Sample. Students studying social pedagogy at Lithuanian universities have been selected as the population of the quasi-experiment. In compiling the sample a few rules have been followed: *the sample of the research has been purposely comprised of only full-time student population; *only senior students (3rd year and 4th year students) have been chosen for the final measurement; *in choosing the experimental and control groups, the requirement (Kardelis, 2007) that the minimum number of cases in the control and experimental group should not be less than 30 has been taken into account; *after selecting a control group in a convenient way, the conditions have been set up so that all students of this groups could participate in the final measurement. Finally, a total of 110 students participated in the experimental and control groups: in the EG - 31 student, in the CG - 79 students.

The quasi-experimental programme. In the course of creating the quasiexperimental programme, it has been referred to the ideas about focusing students' attention on themselves as future professionals, that had been previously identified in the theoretical analysis, that describe that in the development of professional calling during the studies of the social pedagogy study programme focusing students' attention on themselves as future professionals can be provided to a student by introspection, self-analysis, self-reflection and self-monitoring.

The programme was implemented by one of the authors of the present article (Saveljeva, 2016) in her taught subjects and guided practical activities and during students' professional practice. Focusing students' attention on themselves as future professionals was provided to students in accordance with the general ethical principles immediately after the tasks were completed; it was directly related to the purposes of the task and student's exhibited behaviour during the task. Students were prior introduced to the course of the provision of feedback, i.e. the purpose and nature of information provision have been identified, etc. The quasi-experiment was performed in compliance with the principle of voluntarity students were not forced to provide and receive feedback.

The instrument. The post-experimental measuring instrument was developed by Regina Saveljeva (Saveljeva, 2016), by leading of co-author of the present article, referring to the essential features of focusing students' attention on themselves as future professionals, that had been identified during the theoretical analysis, and specifics of the work as a social pedagogue in general education school. The instrument variables were grouped into four groups: introspection, self-analysis, self-reflection and self-monitoring.

Using these variables, ordinal scale was designed to determine students' opinion about the educational impact of focusing students' attention on themselves as future professionals on their professional calling. In the questionnaire 
respondents were asked to rate this impact in a 7-point scale $(1$ - weak impact on the development of professional calling, 7 - strong impact on the development of professional calling).

Methods of data analysis. First of all, several derivative variables have been designed. The derivative variable of the scale of evaluation of an impact of focusing students' attention on themselves as future professionals and derivative variables of subscales - of the first subscale (the impact of introspection on professional calling) of this scale, the second subscale (the impact of self-analysis on professional calling) of this scale, the third subscale (the impact of selfreflection on professional calling) of this scale and of the fourth subscale (the impact of self-monitoring on professional calling) of this scale.

Since it was intended to compare the differences between EG and CG, statistical assumptions have been examined in order to choose the methodology for calculation of differences. Kolmogorov-Smirnov criterion has been used to test the normality of distributions. For cases, the assumption of normality of derivative and primary variables had been violated ( $p<\alpha=0,05)$, Mann-Whitney $\mathrm{U}$ test has been used to determinate differences in the derivative variables of two groups. The variables for which the normality assumption is satisfied ( $p \geq \alpha=$ 0,05), has been calculated Stjudent's t-test.

\section{Results of the research}

The analysis of the impact of focusing one's attention on oneself as a future professional on professional calling has revealed statistically significant differences $(\mathrm{t}=-5,197, \mathrm{df}=108, \mathrm{p}=0,000)$ : the average of evaluations of $\mathrm{EG}$ students $(3,70)$ was higher than that by CG students (average - 2,45). Consequently, EG students had evaluated the impact of activities of focusing one's attention on oneself as a future professional on professional calling more highly than CG students.

Analyzing the impact of introspection on professional calling no statistically significant differences (Mann-Whitney $U=1030,500, p=0,356$ ) have been identified. However, a more detailed analysis has revealed that there were statistically significant differences between the evaluations of EG and CG students of the impact of introspective activity "During my studies I have evaluated my calling as a social pedagogue" on professional calling. EG students (mean rank - 66,13) had evaluated the impact of this introspective activity on professional vocation more highly than CG students (mean rank - 46,97) (Table $1)$.

Analyzing the impact of self-analysis on professional calling some statistically significant differences have been determined $(t=-5,867, d f=101$, $p=0,000)$ : the average of evaluations of EG students $(3,33)$ was higher than that 
Regina Saveljeva, Liudmila Rupšiene. The Impact of Focusing Students' Attention on Themselves as Future Professionals on their Professional Calling

of CG students (average - 1,76). Therefore, EG students had evaluated the impact of the activities of self-analysis on professional calling more highly than CG students.

Table 1 Differences between the evaluations of the impact of introspective activities on professional calling $(\mathrm{N}=110)$

\begin{tabular}{|l|c|c|c|c|}
\hline \multirow{2}{*}{ Variables } & \multicolumn{2}{c|}{ Mean Rank } & \multicolumn{2}{c|}{ Mann-Whitney } \\
\cline { 2 - 5 } & $\boldsymbol{C G}$ & $\boldsymbol{E}$ & $\boldsymbol{U}$ & $\boldsymbol{p}$ \\
\hline I have taken tests on career suitability & 41,73 & 47,42 & 543,000 & 0,356 \\
\hline I have taken tests on self-understanding & 49,75 & 44,94 & 798,500 & 0,426 \\
\hline $\begin{array}{l}\text { During my studies I have evaluated my } \\
\text { professional calling as a social pedagogue }\end{array}$ & 46,97 & 66,13 & 701,000 & 0,002 \\
\hline
\end{tabular}

As shown in Table 2, there were statistically significant differences between the evaluations of EG and CG students of the impact of the three activities of selfanalysis on professional calling. The impact of the following self-analysis activities on professional calling had been evaluated by EG students more highly than by CG students: "During my studies I have analyzed the structure of professional calling" (the average of evaluations of EG - 4,65, of CG - 3,53), "During my studies I have analyzed the structure of pedagogical calling" (EG $4,65, \mathrm{CG}-4,13)$ and "I have participated in the discussion about the calling for the profession of a social pedagogue" (EG-4,68, CG-3.69).

Table 2 Differences between the evaluations of the impact of self-analysis activities on professional calling $(\mathrm{N}=110)$

\begin{tabular}{|l|c|c|c|c|c|}
\hline \multicolumn{1}{|c|}{ Variables } & \multicolumn{2}{c|}{ Mean } & \multicolumn{3}{c|}{ Stjudent's t-test } \\
\cline { 2 - 6 } & $\boldsymbol{C G}$ & $\boldsymbol{E}$ & $\boldsymbol{t}$ & $\boldsymbol{d} \boldsymbol{f}$ & $\boldsymbol{p}$ \\
\hline $\begin{array}{l}\text { During my studies I have analyzed the structure } \\
\text { of professional calling }\end{array}$ & 3,53 & 4,65 & $-3,200$ & 43 & 0,003 \\
\hline $\begin{array}{l}\text { During my studies I have analyzed the structure } \\
\text { of pedagogical calling }\end{array}$ & 4,13 & 4,65 & $-2,100$ & 37,097 & 0,043 \\
\hline $\begin{array}{l}\text { During my studies I have analyzed the structure } \\
\text { of calling as a social pedagogue }\end{array}$ & 4,31 & 4,58 & $-0,902$ & 50 & 0,371 \\
\hline $\begin{array}{l}\text { With my teacher(s) and students in my group } \\
\text { we have discussed how the calling for social } \\
\text { pedagogical activity is formed }\end{array}$ & 4,29 & 4,65 & $-1,213$ & 59 & 0,230 \\
\hline $\begin{array}{l}\text { I have analyzed my calling for the profession as } \\
\text { a social pedagogue }\end{array}$ & 4,37 & 4,91 & $-1,707$ & 73 & 0,092 \\
\hline $\begin{array}{l}\text { I have discussed with my teacher(s) my motives } \\
\text { that had encouraged me to choose the } \\
\text { profession of a social pedagogue }\end{array}$ & 4,60 & 4,88 & $-0,893$ & 34,469 & 0,378 \\
\hline $\begin{array}{l}\text { I have discussed with my teacher(s) my calling } \\
\text { for the profession of a social pedagogue }\end{array}$ & 4,31 & 5,00 & $-1,781$ & 29 & 0,085 \\
\hline
\end{tabular}


SOCIETY. INTEGRATION. EDUCATION

Proceedings of the International Scientific Conference. Volume I, May $26^{\text {th }}-27^{\text {th }}$, 2017. 339-351

\begin{tabular}{|l|c|c|c|c|c|}
\hline $\begin{array}{l}\text { I have discussed with my teacher(s) my } \\
\text { inclination for the profession of a social } \\
\text { pedagogue }\end{array}$ & 4,24 & 4,65 & $-1,310$ & 44 & 0,197 \\
\hline $\begin{array}{l}\text { I have discussed with my teacher(s) my } \\
\text { character traits important for the profession of a } \\
\text { social pedagogue }\end{array}$ & 4,00 & 4,74 & $-2,000$ & 46 & 0,051 \\
\hline $\begin{array}{l}\text { I have discussed with my teacher(s) my skills } \\
\text { relevant for the profession of a social } \\
\text { pedagogue }\end{array}$ & 4,46 & 4,72 & $-0,903$ & 51 & 0,371 \\
\hline $\begin{array}{l}\text { I have participated in the discussion about the } \\
\text { calling for the profession of a social pedagogue }\end{array}$ & 3,69 & 4,68 & $-2,159$ & 30 & 0,039 \\
\hline
\end{tabular}

Analyzing the impact of self-reflection on professional calling statistically significant differences in evaluations have been determined (Mann-Whitney $\mathrm{U}=504,500, \mathrm{p}=0,000)$ : mean rank of EG students $(69,73)$ was higher than that of CG students (mean rank - 42,71). Therefore, EG students had more highly evaluated the impact of self-reflection activities on professional calling.

As it can be seen in Table 3, there were statistically significant differences between the evaluations of EG and CG students of the impact of some selfreflection activities on professional calling. EG students had more highly than CG students evaluated the impact of the following self-reflection activities on professional calling: "With my teacher I have individually discussed my character traits that had encouraged me to choose the profession of a social pedagogue (e.g., during interview, conversation, etc.)" (mean rank of EG - 27,09, CG - 18,06), "I have told to my teacher and students in my group about the events that had encouraged me to choose the profession of a social pedagogue. I have illustrated my narration with pictures" (EG - 34,00, CG - 24,83), "In my practice journal I have written about the changes in my attitude towards the profession of a social pedagogue" (EG - 43,54, CG - 32,28) and "In my practice journal I have written about the changes in my inclination and suitability for the profession of a social pedagogue" (EG - 41,54, CG - 28,60).

Table 3 Differences between the evaluations of the impact of activities of self-reflection on professional calling $(\mathrm{N}=110)$

\begin{tabular}{|l|c|c|c|c|}
\hline \multicolumn{1}{|c|}{ Variables } & \multicolumn{2}{c|}{ Mean Rank } & \multicolumn{2}{c|}{ Mann-Whitney } \\
\cline { 2 - 5 } & $\boldsymbol{C G}$ & $\boldsymbol{E}$ & $\boldsymbol{U}$ & $\boldsymbol{p}$ \\
\hline $\begin{array}{l}\text { With my teacher(s) I have individually discussed the } \\
\text { formation of my calling prior to my studies at the } \\
\text { university (e.g., during interview, conversation, etc.) }\end{array}$ & 16,87 & 19,34 & 130,500 & 0,456 \\
\hline $\begin{array}{l}\text { With my teacher I have individually discussed my } \\
\text { character traits that had encouraged me to choose the } \\
\text { profession of a social pedagogue (e.g., during } \\
\text { interview, conversation, etc.) }\end{array}$ & 18,06 & 27,09 & 118,500 & 0,017 \\
\hline
\end{tabular}




\begin{tabular}{|l|l|l|l|l|}
\hline $\begin{array}{l}\text { With my teacher I have individually discussed my } \\
\text { professional skills that had encouraged me to choose } \\
\text { the profession of social pedagogue (e.g., during } \\
\text { interview, conversation, etc.) }\end{array}$ & 19,86 & 21,28 & 184,000 & 0,679 \\
\hline $\begin{array}{l}\text { I have told to my teacher and students in my group } \\
\text { about the events that had encouraged me to choose the } \\
\text { profession of a social pedagogue. I have illustrated my } \\
\text { narration with pictures }\end{array}$ & 24,83 & 34,00 & 228,000 & 0,037 \\
\hline $\begin{array}{l}\text { In my practice journal I have written about the changes } \\
\text { in my attitude towards the profession of a social } \\
\text { pedagogue }\end{array}$ & 32,28 & 43,54 & 417,500 & 0,023 \\
\hline $\begin{array}{l}\text { In my practice journal I have written about the changes } \\
\text { in my inclination and suitability for the profession of a } \\
\text { social pedagogue }\end{array}$ & 28,60 & 41,54 & 311,500 & 0,006 \\
\hline $\begin{array}{l}\text { In my practice journal I have written about the changes } \\
\text { in my character traits that are relevant for the } \\
\text { profession of a social pedagogue }\end{array}$ & 36,31 & 45,20 & 540,500 & 0,085 \\
\hline $\begin{array}{l}\text { In my practice journal I have written about the changes } \\
\text { in my skills that are relevant for the profession of a } \\
\text { social pedagogue }\end{array}$ & 35,84 & 38,98 & 567,500 & 0,520 \\
\hline
\end{tabular}

The analysis of the impact of self-monitoring on professional calling has not revealed any statistically significant differences between evaluations (MannWhitney $\mathrm{U}=953,000, \mathrm{p}=0,172$ ). However, a more detailed analysis has revealed that there were statistically significant differences between the evaluations of the impact of the two self-monitoring activities on professional calling. EG students (mean rank - 50,06) had more highly than CG students (mean rank - 36,47) evaluated the impact of dynamics, observed during their studies, of their calling for social pedagogical activity on professional calling. CG students (mean rank 40,01) had more highly than EG students (mean rank - 29,84) evaluated the fact that during their studies they had the opportunity to analyze the development / change of their professional skills (Table 4).

Table 4 Differences between the evaluations of the impact of self-monitoring activities on professional calling $(\mathrm{N}=110)$

\begin{tabular}{|l|c|c|c|c|}
\hline \multicolumn{1}{|c|}{ Variables } & \multicolumn{2}{|c|}{ Mean Rank } & \multicolumn{2}{c|}{ Mann-Whitney } \\
\cline { 2 - 5 } & $\boldsymbol{C G}$ & $\boldsymbol{E G}$ & $\boldsymbol{U}$ & $\boldsymbol{p}$ \\
\hline $\begin{array}{l}\text { During my studies I have monitored the } \\
\text { dynamics of my calling for social pedagogical } \\
\text { activity }\end{array}$ & 36,47 & 50,06 & 484,500 & 0,011 \\
\hline $\begin{array}{l}\text { During my studies I have monitored the } \\
\text { development / change of my inclination for the } \\
\text { activity as a social pedagogue }\end{array}$ & 42,69 & 48,83 & 693,500 & 0,280 \\
\hline
\end{tabular}




\begin{tabular}{|l|c|c|c|c|}
\hline $\begin{array}{l}\text { During my studies I have monitored the } \\
\text { development / change of my character traits }\end{array}$ & 46,48 & 48,21 & 876,000 & 0,766 \\
\hline $\begin{array}{l}\text { During my studies I have monitored the } \\
\text { development / change of my professional skills }\end{array}$ & 51,24 & 50,43 & 1048,000 & 0,895 \\
\hline $\begin{array}{l}\text { During my studies I have analyzed the dynamics } \\
\text { of my professional calling }\end{array}$ & 39,23 & 34,31 & 541,000 & 0,326 \\
\hline $\begin{array}{l}\text { During my studies I have analyzed the } \\
\text { development / change of my inclination, } \\
\text { suitability for the profession of a social } \\
\text { pedagogue }\end{array}$ & 41,39 & 40,27 & 721,500 & 0,825 \\
\hline $\begin{array}{l}\text { During my studies I have analyzed the } \\
\text { development / change of my character traits }\end{array}$ & 43,35 & 42,21 & 746,500 & 0,831 \\
\hline $\begin{array}{l}\text { During my studies I had the opportunity to } \\
\text { analyze the development / change of my } \\
\text { professional skills }\end{array}$ & 40,01 & 29,84 & 429,500 & 0,033 \\
\hline
\end{tabular}

\section{Discussion}

Discussion of research findings. According to the results of the research, students that participated in the experimental programme had more highly evaluated the impact of the activities of focusing one's attention on oneself as a future professional on professional calling. Therefore, there is a reason to believe that such focus on oneself as a future professional contributes to the development of students' professional calling. These results are confirmed by other researchers' (Hirschi \& Herrmann, 2012; Wrzesniewski, 2012; Elangovan et al., 2010; Duffy \& Sedlacek, 2010; Dik et al., 2009; Dik \& Steger, 2008; Hall \& Chandler, 2005 ) ideas on the effect of focusing one's attention on one self when developing professional calling.

The analysis of the research results has revealed that there is a statistically significant difference only between the evaluations of the impact of some activities of focusing one's attention on oneself as a future professional on professional calling, namely, the activities of self-analysis and self-reflection. The results of the present research can be compared to other studies that note the importance of self-analysis and self-reflection for the clarity of the self- concept (Duffy et al., 2011), and Professional self (Duffy et al., 2014; Duffy \& Dik 2013; Duffy et al., 2011), since self-analysis and self-reflection encourage to look for one's calling more (Woitowicz \& Domene, 2013). Higher evaluations of the impact of those activities on professional calling by EG students are related to some researchers' studies, where it is stated that the following means are important for the development of professionals: the narrative act (open act of self-reflection) (Kelchermans, 2005), biographical interviews (Kelchtermans \&Vandenberghe, 1994), professional biographies or career stories (Kelchtermans, 2005); the analysis of personal stories, life histories (Wolf et al., 2000; Sikes \& Everington, 
2001), as well as personal learning experience prior to studies and during the study period help individuals to better understand their profession and themselves (Kelchtermans \& Vandenberghe, 1994; Furlong, 2011; Haggarty \& Postlethwaite, 2012; Chang-Kredl \& Kingsley, 2014). In the scientific literature (Polonsky, 2011; Barry \& O'Callaghan, 2009), reflective journal writing is noted not only as a means developing the skills of reflection, critical thinking, integration of theory with practice, but also as a means promoting professional growth and developing students' self-awareness. The results of the quasi-experiment have revealed that EG students had evaluated the impact of these activities on professional calling more highly than CG students. This indicates the importance of this activity in developing students' professional calling.

According to the results of the research it can be concluded that professional calling is actually an evolving construct, as it is noted by other researchers (e.g., Wrzesniewski, 2012; Hunter et al., 2010; Dik \& Duffy, 2009). Moreover, the research confirms the assertion by other researchers (e.g., Praskova et al., 2014; Woitowicz \& Domene, 2013; Danilevičius, 2013) that higher education institutions play an important role in the development of students' professional calling.

The obtained results are also relevant for the development of the concept of development of professional calling in another way. As it has been already mentioned, a number of educational aspects of the development of professional calling have been disclosed so far, but there was a lack of empirical evidence proving the fact of the impact of focusing students' attention on themselves as future professionals on their professional calling. The empirical evidence obtained in the course of the empirical research contributes to the solution of this scientific problem.

Limitations of the research. The implementation of the quasi-experimental programme had been conditioned by some limitations of the pedagogical experiment. Management limitations of the experimental system should be mentioned. The development of future social pedagogues in a university depends on activities of many teachers that are not always compatible with each other. During the implementation of the programme, different teachers' activities have not been coordinated. It had been done only by one of the authors of the present article when she was teaching students of the mentioned study programme several subjects. The results should be interpreted with caution and due to the fact that respondents have rated the impact of providing feedback on their professional calling by themselves, thus the results are more a reflection of their self-perception and self-report, they are also quite subjective. It is necessary to mention the fact that the empirical research has included only the main case of full-time studies of social pedagogy, thus the results of the research more reliably reflect only this case. 
Recommendations. It is recommended to higher school teachers who aim to develop students' professional calling to organize the provision of focusing students' attention on themselves as future professionals by modifying some of the elements according to the standards of professional education, to promote students' interest and to develop their professional calling.

\section{Conclusions}

Generalization of research findings resulted in the following conclusions:

The results of research show that those students who focus more on themselves as future professionals evaluated the impact of those activities on the development of professional calling more highly than other students. Referring to the results of the empirical research and their analysis, it can be stated that focusing students' attention on themselves as future professionals during their studies play an important role in developing students' professional calling.

\section{References}

Altinay, Z., \& Altinay, F. (2012). An evaluation of school experience courses: The development of observation and reflection competences of prospective teachers. Procedia - Social and Behavioral Sciences, 55, 87-93.

Barry, P., \& O'Callaghan, C. (2008). Reflexive journal writing. Nordic Journal of Music Therapy, 17 (1), 55-66.

Bubnys, R. (2012). Reflektyvaus mokymo(si) metody diegimo aukštojoje mokykloje metodika: refleksija kaip besimokančiuju asmenines ir profesiness raidos didaktinis metodas. Šiauliai: Šiaulių valstybinè kolegija.

Chang-Kredl, S., \& Kingsley, S. (2014). Identity expectations in early childhood teacher education: Pre-service teachers' memories of prior experiences and reasons for entry into the profession. Teaching and Teacher Education, 43, 27-36.

Danilevičius, E. (2013). Profesinio pašaukimo identifikavimo kompetencijos ugdymas asmenybès tiesos apie save pažinimo prielaida. LOGOS, 76, 91-100.

Dik, B. J., Duffy, R. D., \& Eldridge, B. (2009). Calling and vocation in career counseling: Recommendations for promoting meaningful work. Professional Psychology: Research and Practice, 40, 625-632.

Dik, B. J., \& Steger, M. F. (2008). Randomized trial of a calling-infused career workshop incorporating counselor self-disclosure. Journal of Vocational Behavior, 35 (2), 203-211.

Dobrow, S., \& Tosti-Kharas, J. (2011). Calling: The development of a scale measure. Personnel Psychology, 64, 1001-1049.

Duffy, R. D., Allan, B. A., \& Bott, E. M. (2012). Calling and life satisfaction among undergraduate students: Investigating mediators and moderators. Journal of Happiness Studies, 13, 469-479.

Duffy, R. D., Allan, B. A., \& Dik, B. J. (2011). The presence of a calling and academic satisfaction: Examining potential mediators. Journal of Vocational Behavior, 79, 74-80.

Duffy, R. D., \& Dik, B. J. (2013). Research on calling: What have we learned and where are we going? Journal of Vocational Behavior, 83, 428-436. 
Duffy, R. D., \& Sedlacek, W. E. (2007). The presence of and search for a calling: Connections to career development. Journal of Vocational Behavior, 70, 590-601.

Duffy, R. D., \& Sedlacek, W. E. (2010). The salience of a career calling among college students: Exploring group differences and links to religiousness, life meaning, and life satisfaction. The Career Development Quarterly, 59 (1), 27-41.

Ivanauskienè, V., \& Liobikienè, N. (2005). Socialinio darbo studentų savirefleksijos gebëjimų ugdymas teoriniuose kursuose. Socialinis darbas, Nr.4(1), 118-121.

Elangovan, A. R., Pinder, C. C., \& McLean, M. (2010). Callings and organizational behavior. Journal of Vocational Behavior, 76, 428-440.

French, J. R., \& Domene, J. F. (2010). Sense of „calling”: An organizing principle for the lives and values of young women in university. Canadian Journal of Counselling \& Psychotherapy, 44, 1-14.

Furlong, C. (2013). The teacher I wish to be: Exploring the influence of life histories on student teacher idealized identities. European Journal of Teacher Education, 36, 68-83.

Green, J. L., Camilli, G., \& Elmore, P. B. (2006). Handbook of Complementary Methods in Education Research. New York: Routledge.

Haggarty, L., \& Postlethwaite, K. (2012). An exploration of changes in thinking in the transition from student teacher to newly qualified teacher. Research Papers in Education, 27, 241262.

Hagmaier, T., \& Abele, A. E. (2012). The multidimensionality of calling: Conceptualisation, measurement and a bicultural perspective. Journal of Vocational Behavior, 81, 39-51.

Hall, D. T., \& Chandler, D. E. (2005). Psychological success: When the career is a calling. Journal of Organizational Behavior, 26, 155-176.

Hirschi, A. (2012). Callings and work engagement: Moderated mediation model of work meaningfulness, occupational identity, and occupational self-efficacy. Journal of Counselling Psychology, 59 (3), 479-485.

Hirschi, A., \& Herrmann, A. (2012). Vocational identity achievement as a mediator of presence of calling and life satisfaction. Journal of Career Assessment, 20 (3), 309-321.

Hirschi, A., \& Herrmann, A. (2013). Calling and career preparation: Investigating developmental patterns and temporal precedence. Journal of Vocational Behavior, 83 (1), 51-60.

Hunter, I., Dik, B. J., \& Banning, J. H. (2010). College students' perceptions of calling in work and life: A qualitative analysis. Journal of Vocational Behavior, 76, 178-186.

Kavaliauskienè, V. (2001). Pedagoginis pašaukimas ir jo ugdymas. Klaipėda: Klaipėdos universiteto leidykla.

Kelchtermans, G. (2005). Teachers' emotions in educational reforms: Self-understanding, vulnerable commitment and micropolitical literacy. Teaching and Teacher Education, 21, 995-1006.

Kelchtermans, G., \& Vandenberghe, R. (1994). Teachers' professional development: A biographical perspective. Journal of Curriculum Studies, 26, 45-62.

Polonsky, K. (2011). Diary writing and creativity: A qualitative case study of selfconsciousness. Leading Undergraduate Work in English Studies, 3, 327-341.

Praskova, A., Hood, M., \& Creed, P. A. (2014). Testing a Calling Model of Psychological Career Success in Australian Young Adults: A Longitudinal Study. Journal of Vocational Behavior, 85, 125-135.

Roberts, L. M., \& Creary, S. J. (2012). Positive identity construction: Insights from classical and contemporary theoretical perspectives. In Cameron, K. S., Spreitzer, G. M. (eds). The 
Oxford handbook of positive organizational scholarship. New York: Oxford University Press.

Rusche, S. N., \& Jason, K. (2011). „You have to absorb yourself in it”: Using inquiry and reflection to promote student learning and self-knowledge. Teaching Sociology, 39 (4), $338-353$.

Rupšienė, L., \& Rutkienė, A. (2016). Edukacinis eksperimentas. Klaipėda: Klaipėdos u-to leidykla.

Saveljeva, R. (2016). Studentu profeinio pašaukimo ugdymas plètojant profesinę svimone (socialines pedagogikos studiju programos atvejis) (Doctoral dissertation thesis). Klaipèda university, Klaipėda.

Saveljeva, R., \& Rupšienè, L. (2016). The impact of providing feedback to students as future professionals on their professional calling. Social Welfare, 2 (6), 74-87.

Saveljeva, R., Petružienè, S., \& Braslauskienè, R. (2011). Socialinių pedagogų rengimo kokybės gerinimas plètojant studijuojančiųu profesinį pašaukimą ir karjeros viziją. Tiltai, 3 (56), 125-135.

Sikes, P., \& Everington, J. (2001). Becoming an RE teacher: A life history approach. British Journal of Religious Education, 24 (1), 8-19.

Steger, M. F., Pickering, N. K., Shin, J. Y., \& Dik, B. J. (2010). Calling in Work. Secular or Sacred? Journal of Career Assessment, 18 (1), 82-96.

Wolf, S. A., Ballentine, D., \& Hill, L. A. (2000). „Only connect!” Cross-cultural connections in the reading lives of preservice teachers and children. Journal of Literacy Research, 32, 533-569.

Woitowicz, L. A., \& Domene, J. F. (2013). Relationships between calling and academic motivation in postsecondary students. Canadian Journal of Counselling and Psychotherapy, 47 (4), 460-479.

Wrzesniewski, A. (2012). Callings. In K. S. Cameron, G. M. Spreitzer (Eds.), The Oxford handbook of positive organizational scholarship (pp. 45-55). Oxford, UK: Oxford University Press. 